\title{
A new way of looking at Manet: the revelations of radiography
}

\author{
JOHN LOVEDAY
}

One of the advantages of painting in oils is that the picture may be changed as work proceeds. Figures can be painted in or out, postures can be changed, and even the shape of the picture can be altered. The exhibition "The Hidden Face of Manet" (an investigation of the artist's working process), held at the Courtauld Institute

added to change the shape. Some figures had been painted out and others added. For example, in the painting of Olympia, the cat on the end of the bed had obviously been added later. Similarly $L e$ Déjeuner sur l'Herbe, the painting that caused such a furore when first exhibited at the Salon des Refusés in 1863, underwent many changes during its execution. Originally, there was a wide open landscape instead of the trees on the left, and the

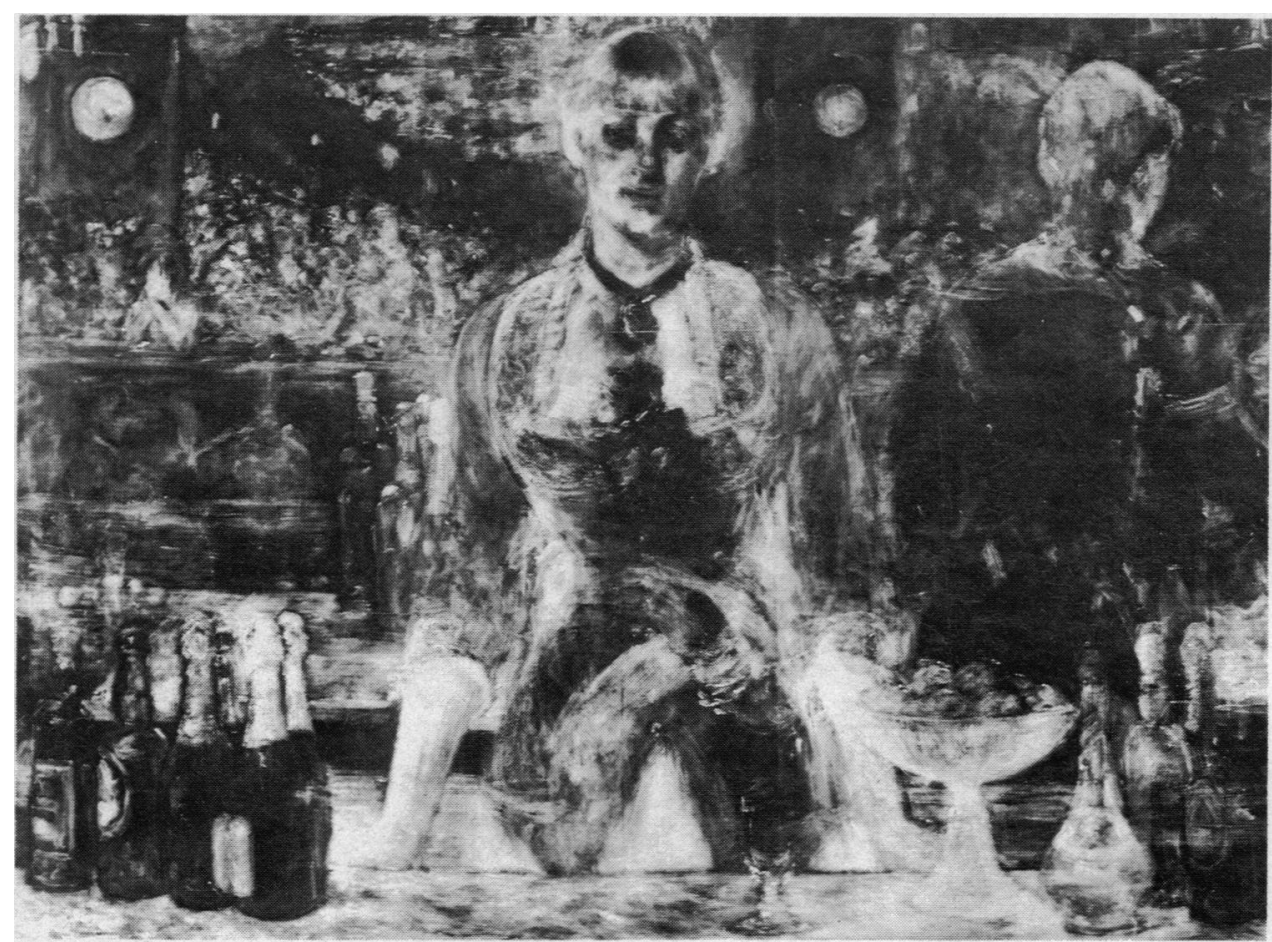
clothes and food in the foreground of the painting were added later. $X$ ray pictures of the justly popular painting Un Bar aux Folies Bergère showed that the barmaid's arms were originally crossed in front of her waist.

I am indebted to Dr Stephen ReesJones, the technical director of the Courtauld Institute, for giving me further information about the technique of $x$ raying paintings. The radiographs in the exhibition were presented as positive prints and showed remarkably clearly some of the changes that had occurred during the execution of the paintings. The technique of $x$ raying paintings is now well established, but at the Courtauld Institute the equipment is certainly basic -an old Philips portable medical machine. The average exposure factors are $18-20 \mathrm{kV}, 10 \mathrm{~mA}$ for 16 seconds. The anode of the machine is now very worn, however, and the exposure time is gradually having to be increased still further. Kodak CX nonscreen industrial film is used. In spite

Galleries in the spring of 1986 , illustrated this perfectly. Radiographs of some of Manet's paintings were displayed alongside the actual pictures. As a radiologist and an amateur oil painter, I had a twofold interest in the exhibition.

\section{Manet's way of working}

Although Manet occasionally made some preliminary sketches and watercolours, he usually painted directly on to his canvas. While working he evidently rubbed out and repainted incessantly. The $x$ ray pictures in the exhibition certainly confirmed this. Some of the smaller pictures had obviously been cut from larger works, and some had extra strips of canvas

\footnotetext{
Royal Surrey County Hospital, Guildford, Surrey

JOHN LOVEDAY, FRCR, consultant radiologist
}

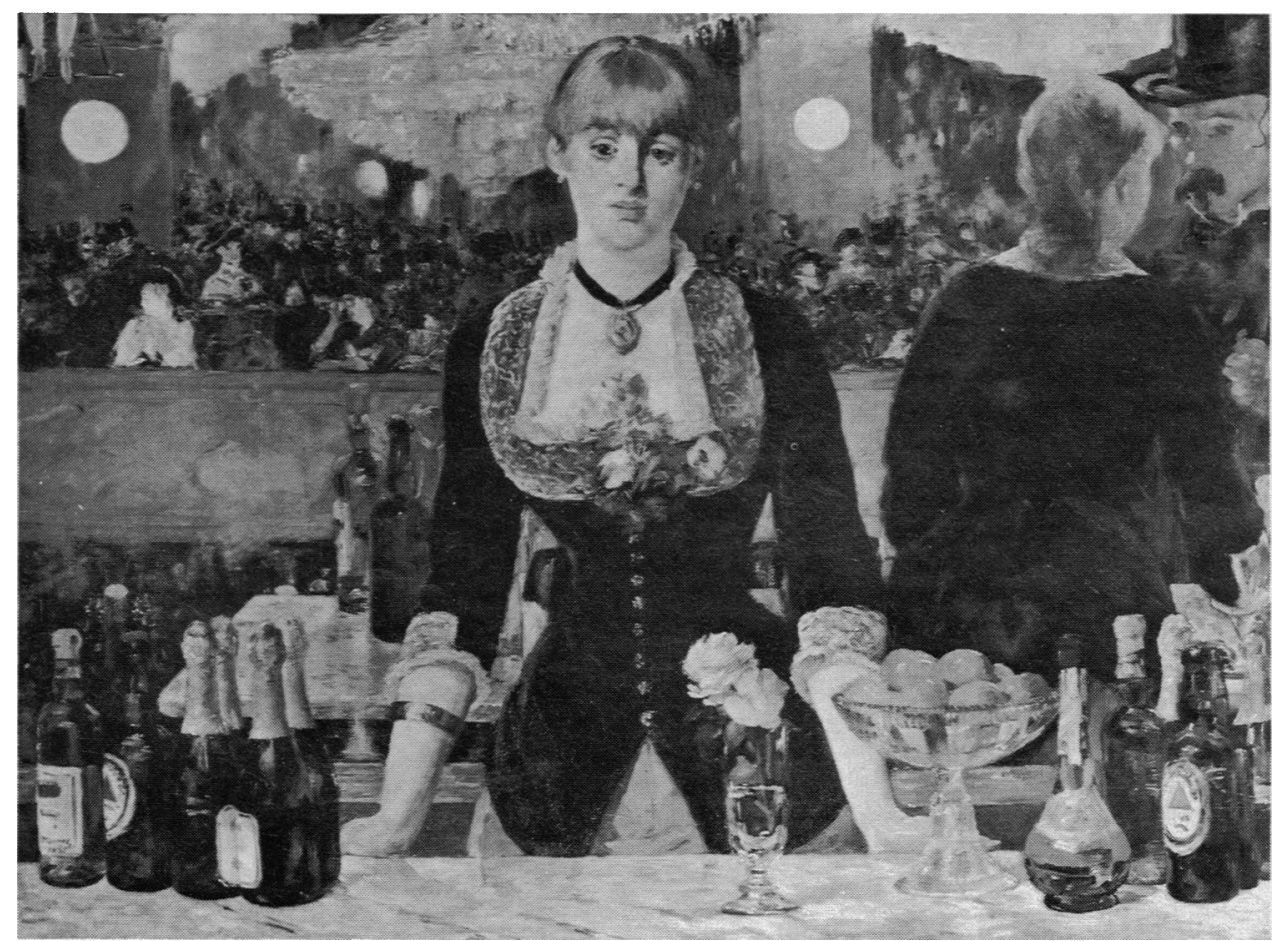


of this rather unsophisticated approach, the radiographs are remarkably clear owing largely to the metallic pigments contained in oil paints. White paint contains lead and is obviously the most radio-opaque pigment. The varying amount of white mixed with other colours provides a readable image. Other colours, such as cadmium blue, also contain metallic pigments, and there is mercury in vermilion. The detail provided by the $x$ ray images is often good enough to show the artist's actual brush strokes, revealing sufficient variations in technique to help establish the authenticity of paintings.

\section{Reflections on technique}

While at the Courtauld Galleries I took the opportunity to look at some of the other paintings, which included some beautiful portraits by Reubens and a selection of his modelli. Modelli are preliminary smaller oil paintings which he used to show as samples to prospective customers. Reubens was very methodical in his work. He would undertake a preliminary sketch in pen and ink, then he would paint a modello. If this was acceptable to his client he would then undertake some detailed drawings of the various figures before finally undertaking the large final painting.

There is also a small but impressive collection of Impressionist paintings in the galleries, including the beautiful La Loge by Renoir and Autumn at Argenteuil by Monet; this painting of Monet's is the epitome of Impressionism and has a delightful spontaneity. I could not imagine Monet either making detailed plans like Reubens or changing his mind like Manet.
A few days after my visit to the Manet exhibition I was on holiday in Germany and saw the magnificent ceiling frescoes painted by Tiepolo in the Residenz Palace in Wurzburg. One, above the staircase, portrays the four continents and is the largest painting in the world. The fresco technique is to paint on wet plaster so that the paint is absorbed into the drying surface. Thus Tiepolo had to work very fast while standing on scaffolding painting above his head. Today the colours are as vivid as ever and the figures appear quite lifelike when viewed from the ground. They have a wonderful perspective and some appear almost three dimensional. As I looked at these materpieces by Tiepolo I began to have reactionary thoughts about Manet.

Manet is reputed to have had a brilliant technique. "Manet was a superb technician" (Oxford Companion to Art); "He painted directly onto the canvas, which gives his work a great zest and vitality" (Marina Vaizey, art critic of the Sunday Times). I rather disagree; I think the $x$ ray pictures in the exhibition revealed a rather protracted and laboured technique which compares unfavourably with the confident sureness of touch of earlier artists such as Reubens and Tiepolo and with the fresh spontaneity of the Impressionists who followed him. They suggest that he had no definite vision of how the final picture should look. I know from my own efforts that if I have no clear image and have to change my painting during its execution it is rarely a success. It was a fascinating exhibition, particularly from the radiological view, but it slightly diminished my admiration for Manet's work.

The pictures of Un Bar aux Folies Bergère were reproduced by permission of the Burlington Magazine.

\section{MATERIA NON MEDICA}

\section{Sheep may-or may not-safely graze}

I have always looked on our annual golf weekend as one of the few sixpences in the Christmas pudding of life. But this year the coin quickly became tarnished and, like the pound, sank to its lowest level ever.

I suppose we had become used to only the best: the finest Scottish courses basking in the autumn sun; four type A personalities locked in a duel now 10 years old; and a rubber or two of coarse bridge to while away the evenings. But somehow this time the omens had never been good. The rain fell heavily, and the woodlined cottage we were staying in was singed by pipe ash carelessly knocked out into a plastic bucket. Still, after a day wading round the course at Nairn we were able to do battle in watery sunshine over Royal Dornoch, now rated as the tenth best course in the world. That evening, the matches nicely poised, we were cruising back along the smart new roads of the Black Isle towards the mirage of a large steak.

Snug in a rear passenger seat, my brain in neutral, purring over my latest victory, I was rudely awakened when I was forced to nuzzle the back of the driver's seat as the car braked sharply. I heard a bump and the tinkle of broken glass.

We parked at the side of the road and peered back through the mist at two sheep lying in the middle, one like a caricature of death with all four of its legs pointing up to the sky. Soon cars from both directions were braking and swerving, and pounding into the sheep. Brave men risked being savaged by the dead sheep, and by the screaming metal monsters, as they dragged the bodies to the side of the road

We felt that the farmer should be told about the fate of his sheep and urged to stitch up his property more tightly. The main road joining the Kessock bridge to the north has become a race track, and a few wisps of barbed wire around a field are no longer enough. We were turning right into the farm when a red battering ram of a car hammered into us amidships, joining us in a whirling tango down the main road.

For a whil: I thought I was dead. But after a few stumned seconds my larynx came to life, spitting out phrases I thought I had shed when I left the Royal Navy. It helped a bit and soon my arms came to life, beating at the doors, directed by my nose and ears which had become aware of petrol sloshing out of the burst tank. This was serious; but the crumpled side doors would not open from the inside. I wormed my way out via the north face of the boot, over a fankle of golf clubs and bags; others shoehorned themselves through the windows and soon the walking wounded were standing in a shocked group by the side of the road, talking in the wobbly tones of Larry the Lamb.

The world was dark and misty and now strangely blurred. My hands explored my face, finding blood but no glasses. Groping in the petrol lake, I rescued two pairs and wore each for a while before realising that they were not mine. I groped over to the other car, where there were some broken necks, and tried to see that everything was being done for them. Dermatologists are forever writing clever articles about what fun it would be to play at dermatology blindfold: it was no fun trying to do casualty work.

I was delighted when the police came quickly to us. They were calm, kind, efficient, and polite, if a little obsessed with their paperwork. My date of birth had been taken three times before I went in one of the three ambulances to Raigmore Hospital, where the most dented among us were detained.

Next day I found out again how much I needed my glasses after three unsuccessful shaves with a disposable razor, whose protective blade cover I had not spotted. Accordingly, I returned to the scene of the accident, hoping to find a few splinters from my lenses which might be moulded together into a monocle.

The sheep were still lying by the road looking like burst paper bags. I paced out the skidmarks - 50 yards from the red car before it hit us, and then 30 yards with the cars locked together. The dead cars had been carted off to their graveyard, and I saw no reason to doubt the verdict of the police and ambulance men that we would have been carted off too had we not been in a car with special steel bars protecting the passenger compartment. The soft tissue of the doors had been pushed in a bit, like plasticine through a sieve, but the girders had held.

What lessons can be learnt from this tale? Keep mutton off the roads, perhaps. No longer can I get to sleep counting sheep jumping over a fencethat way lies a nightmare. More important, one's choice of a car should depend not on its sprinting qualities or gaudy paintwork but solely on the ability of its body to stand up to the attacks of battering rams and batty ewes.

J A SAVIN, consultant dermatologist, Edinburgh. 